\title{
DNA barcode of Enggano hill myna, Gracula religiosa enganensis (Aves: Sturnidae) based on mitochondrial DNA cytochrome oxidase subunit I
}

\author{
JARULIS", CHOIRUL MUSLIM", SANTI NURUL KAMILAH ${ }^{v \vee v, ~ A H M A T ~ F A K H R I ~ U T A M A ~}{ }^{v \vee v ", ~}$

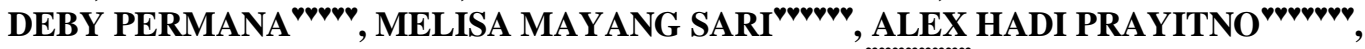

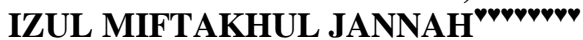 \\ Department of Biology, Faculty of Mathematics and Natural Sciences, Universitas Bengkulu. J1. WR. Supratman, Kandang Limun, Bengkulu 38371, \\ Bengkulu, Indonesia. Tel./fax.: +62-736-20919. ^email: jarulis@unib.ac.id, ${ }^{\text {v }}$ choirulmuslim@unib.ac.id, vw santi.nurul.kamilah@unib.ac.id,

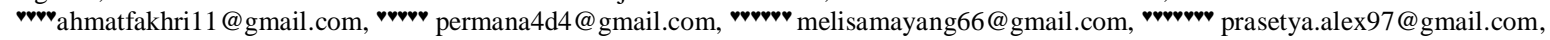
rvrvrvrvizul.miftahul@gmail.com

Manuscript received: 29 December 2020. Revision accepted: 6 February 2021

\begin{abstract}
Jarulis, Muslim C, Kamilah SN, Utama AF, Permana D, Sari MM, Prayitno AH, Jannah IM. 2021. DNA barcode of Enggano hill myna, Gracula religiosa enganensis (Aves: Sturnidae) based on mitochondrial DNA cytochrome oxidase subunit I. Biodiversitas 22: 1635-1643. The sharp decline of the Enggano hill myna population due to illegal trading and habitat degradation needs to be our concern to prevent this bird from extinction. Taxonomically, Enggano hill myna is referred to as a sub-species, but this has not been confirmed by genetic data. We have sequenced seventeen Enggano hill myna mitochondrial DNA COI genes to describe their genetic identity (barcode), genetic distances, and phylogeny. DNA genome from seventeen blood samples was isolated with DNeasy ${ }^{\circledR}$ Blood and Tissue Kit Qiagen, while PCR amplification was performed using a pair primers, namely COIGRF (5'TTCTGATTCTTTGGCCATCC-3') and COIGRR (5'-GTTGGAAGGCTTTGCGTTTA-3'). We used Clustal W alignment in MEGA 10.2.2 software to search single nucleotide polymorphisms. Genetic distance was analyzed by using the Kimura 2-parameter, and the phylogenetic tree was reconstructed with Neighbor-Joining models. We found $98.60 \%$ conservative sites, $0.69 \%$ parsimony sites, and $0.83 \%$ singleton sites from the $716 \mathrm{bp}$ sequence. The highest nucleotide composition was cytosine (32.20\%), and the lowest was guanine (16.80\%), followed by $49 \%$ GC content. Seven SNP sites were found in 716 bp COI gene sequences of seventeen individuals. The genetic distance between Enggano hill myna individuals was ranged from 0.0-0.8\%, and all Enggano hill myna individuals separated from Chinese and Indian populations in the phylogenetic tree with a genetic distance of $0.9 \%$ and $1.1 \%$. Our data suggest that the Enggano hill myna population is still classified as a sub-species. The COI gene sequences that we found can be used to quickly identify this species and are also important to prevent illegal trading in Indonesia.
\end{abstract}

Keywords: Conservation, DNA barcode, phylogenetic, taxonomy, wildlife trafficking

\section{INTRODUCTION}

Enggano hill myna Gracula religiosa enganensis is a sub-species of Gracula religiosa (Aves: Sturnidae) distributed in the Enggano Island, Indonesia. In Indonesia, there are six sub-species of common hill myna; G. religiosa religiosa (Sunda Besar), G. r. miotera (Simeulue), G. r. batuensis (Mentawai, Batu), G. r. enganensis (Enggano), G. r. robusta (Nias, Babi, Banyak), and G. r. venerata (Sumbawa-Alor) (Dominic et al. 2020). Previously, Eaton et al. (2016) mentioned only five sub-species, without $G$. $r$. myotera. This bird is listed as protected species (Anon 2018). It is characterized by shiny black body, white patches on wings, orange beak, yellow legs, and yellow wattle (MacKinnon et al. 2010). The shape of wattle is distinguishable for each sub-species.

A sharp decline in population is threatening the existence of Enggano hill myna. The declined population of Enggano hill myna is caused by deforestation and illegal trade. Deforestation in Enggano Island is caused by the expansion of local community plantation areas for banana, chocolate, 'jengkol', etc. The illegal trading of Enggano hill myna has been going on for a long time. Local people hunt these birds directly from their natural habitat. The birds hunted are young chicks less than seven days old that are in the nest hole and cannot fly. Meanwhile, adult birds are rarely caught because they are difficult to train to produce good sound according to traders' criteria. The harvested birds are traded on the black market in Bengkulu Province and other provinces in Indonesia. Control of these two factors needs to be performed; thus, the rate of decline in this bird population can be inhibited. Biodiversity conservation, including genetic resources, is also important for the future development of science and technology (Susanti 2011).

The taxonomic status of Enggano hill myna is still one of the hot discussion topics for ornithological scientists around the world. The Enggano hill myna division into sub-species still uses the morphological characters (Eaton et al. 2016). In contrast, some authors have not separated common hill myna Gracula reliogiosa into sub-species (Harrisson and Greensmith 2003; Sukmantoro et al. 2007; MacKinnon et al. 2010). The morphological similarities between common hill myna sub-species often lead to misidentification in the field, especially by law enforcement officials and traders. For this reason, the 
classification of the sub-species of Enggano hill myna based on these morphological characters needs to be supported by genetic data.

The genetic information about common hill myna, including the Enggano hill myna sub-species, is still limited. Sibley and Ahlquist (1990) registered this species into the Sturnidae family of the genus Gracula based on DNA hybridization. Analysis of blood protein polymorphisms in sub-species of Nias hill myna, Medan hill myna, and Irian hill myna was carried out by Siregar (1997). Suzanna (2007) classified four sub-species of common hill myna based on blood profiles (erythrocytes, hemoglobin, hematocrit values, and leucocytes) and D-loop mtDNA fragment. The Medan and Nias hill myna is in the same group as the northern Thailand hill myna, while they are sister to Kalimantan common hill myna despite geographically closer to the latter. Lovette and Rubenstein (2007) classified Enggano hill myna into the sub-species $G$. $r$. religiosa and closely related to $G$. $r$. indica. Phylogenetic tree based on the ND2 mtDNA gene shows Gracula religiosa religiosa is more closely related to $G$. $r$. miotera (Dominic et al. 2020). However, none of these studies used the COI mtDNA gene for species barcodes (Hebert et al. 2003a, b; Hebert et al. 2004; Sammler et al. 2011; Gonzales et al. 2013). We can conclude that our research is the first one carried out in the world.

This study aimed to determine the genetic characteristics of Enggano hill myna based on the COI mtDNA gene, determine single nucleotide polymorphism (SNP), and measure genetic distance and its relationship with another common hill myna in the world. The COI mtDNA sequence of Enggano hill myna that we studied could be implemented for species identification and assist the conservation efforts in Indonesia.

\section{MATERIALS AND METHODS}

\section{Sample collection}

The Enggano hill myna used in this study were birds caught by local people in Enggano Island and trafficked illegally in Bengkulu Province and its surroundings. Blood samples were collected from 17 Enggano hill myna (Table 1), which inhabited separately in Enggano island (12 birds, Figure 1), Seluma District (4 birds), Bengkulu City (2 birds) from June to August 2020. The 0.1-0.5 mL blood was micro-piped through the carpal joints vein and preserved following Seutin et al. (1991). Furthermore, these birds are handed back to the owner. The molecular analysis was carried out in the Laboratory of Molecular Biology, Department of Biology, Bengkulu University. This research has received permission from the BKSDA Bengkulu with a decree No. 1459/K.10/TU/PPN/08/2020 and approved by Animal Ethics Committee of Bengkulu University with certificate No. 42 /KEH-LPPM/EC/2020.

\section{Procedures}

\section{Isolation and purification}

Blood samples from the 17 birds were preserved in EDTA at $-20^{\circ} \mathrm{C}$ as much as $10-15 \mu \mathrm{L}$ blood was distributed into a $1.5 \mathrm{~mL}$ Eppendorf tube. The Spin-Column Protocol was used to extract genome DNA, mediated with DNeasy Tissue Kit ${ }^{\circledR}$ Blood and paint No. 69504 (50) procured from Qiagen.

\section{Amplification and sequencing}

The COI gene nucleotide was amplified using the polymerase chain reaction (PCR) procedure to detect any difference therein. Primer designing was through Primer 3 (accessed on http://bio-info.ut.ee/primer3-0.4.0/primer3), while gene alignment was guided by Common Hill Myna Gracula religiosa gene from GenBank (accession no. JF937590). The primers were named COIGRF (5'TTCTGATTCTTTGGCCATCC-3') and COIGRR (5'GTTGGAAGGCTTTGCGTTTA-3') and produced in 750 bp nucleotides. The amplification was performed in SimpliAmp ${ }^{T M}$ Thermal Cycler machine, Applied Biosystems.

The reaction mixture consisted of $9.8 \mu \mathrm{lddH} 2 \mathrm{O}, 5.0 \mu \mathrm{l}$ Enhancer, 5.0 $\mu \mathrm{l}$ Qs buffer, 1.0 $\mu \mathrm{l} \mathrm{dNTP,} 1.0 \mu \mathrm{l}$ forward and reverse primer $(20 \mathrm{pmol} / \mu \mathrm{l}), 0.2 \mu \mathrm{l}$ Taq polymerase and 1-2 $\mu$ l DNA template. The PCR performed temperature sequences were $95^{\circ} \mathrm{C}$ for pre-denaturation (4 minutes), $94^{\circ} \mathrm{C}$ for denaturation ( 1 minute), $57^{\circ} \mathrm{C}$ for annealing (45 seconds), and $72^{\circ} \mathrm{C}$ for extension (1 minute). Further sequencing was conducted at First Base laboratory (Malaysia), using the amplified DNA stored within $1.2 \%$ agarose gel (Sambrook et al. 1989).

Table 1. The number of samples used for analysis

\begin{tabular}{lcl}
\hline \multicolumn{1}{c}{ Sample code } & Blood vol. $(\mathbf{m L})$ & \multicolumn{1}{c}{ Location } \\
\hline BE1 & $0.1-0.5$ & Seluma District \\
BE2 & $0.1-0.5$ & Seluma District \\
BE3 & $0.1-0.5$ & Seluma District \\
BE4 & $0.1-0.5$ & Seluma District \\
BE5 & $0.1-0.5$ & Bengkulu City \\
BE6 & $0.1-0.5$ & Bengkulu City \\
BE7 & $0.1-0.5$ & Enggano Island \\
BE8 & $0.1-0.5$ & Enggano Island \\
BE9 & $0.1-0.5$ & Enggano Island \\
BE10 & $0.1-0.5$ & Enggano Island \\
BE11 & $0.1-0.5$ & Enggano Island \\
BE12 & $0.1-0.5$ & Enggano Island \\
BE13 & $0.1-0.5$ & Enggano Island \\
BE14 & $0.1-0.5$ & Enggano Island \\
BE15 & $0.1-0.5$ & Enggano Island \\
BE16 & $0.1-0.5$ & Enggano Island \\
BE17 & $0.1-0.5$ & Enggano Island \\
\hline
\end{tabular}




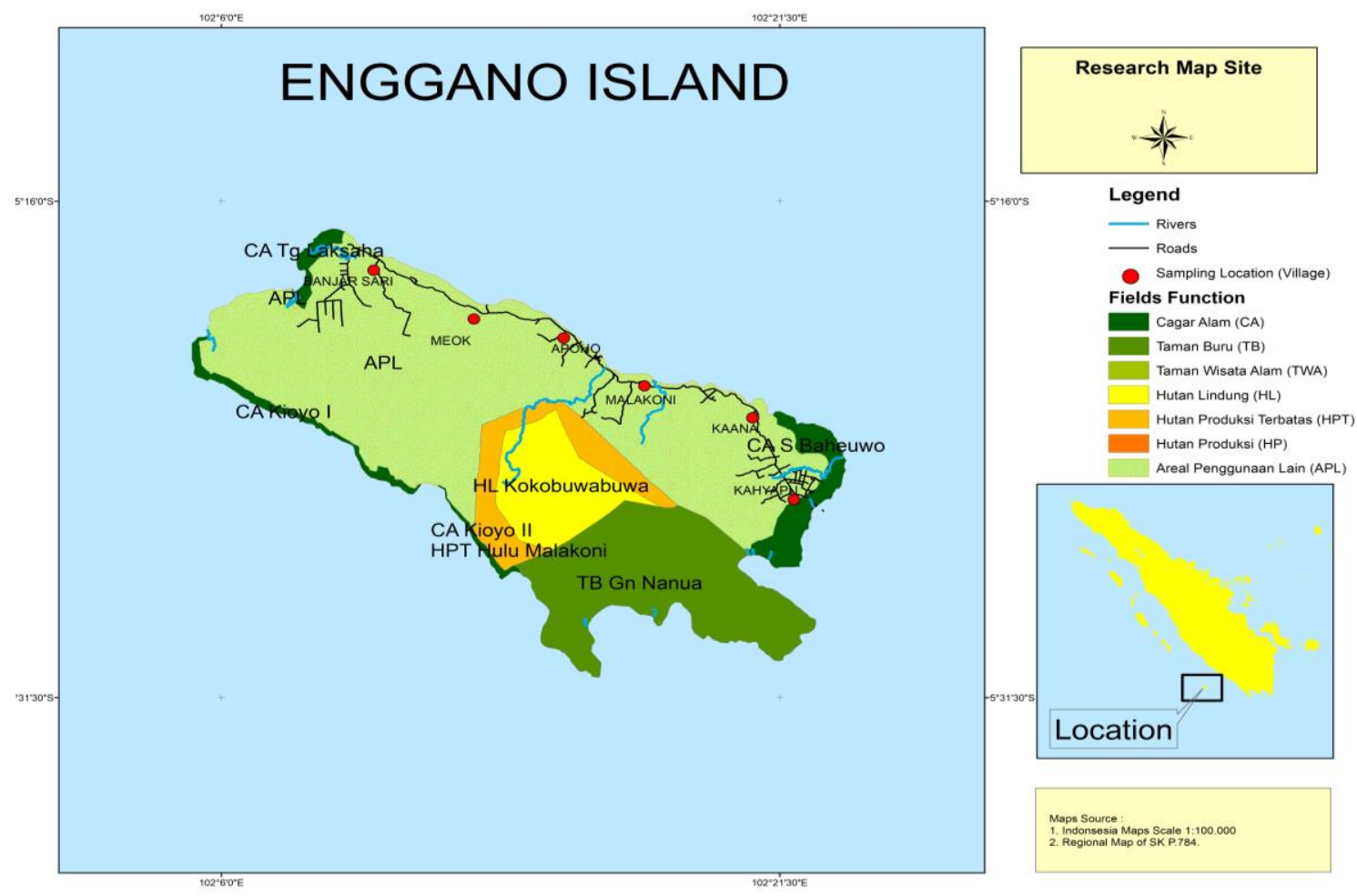

Figure 1. The map of Enggano Island, southwest of Sumatra, Indonesia as Enggano hill myna (Gracula religiosa enganensis) habitat

\section{Data analysis}

Editing and alignment of nucleotides were mediated by Clustal W run through MEGA 10.2.2 software (Kumar et al. 2018). Sequences were then checked and trimmed with BIOEDIT version 7.0.9 (Hall 1999). All samples were successfully aligned into 716 bp before imported to the Barcode of Life Database (BoLD) System in http://www.barcodinglife.org website to determine the sample similarity. The genetic distances were determined based on the Kimura 2-parameter (K2P) method (Kimura 1980). We reconstructed the phylogenetic tree using Neighbor-Joining (NJ) models with 1000 bootstrap repetitions (Kumar et al. 2018). Three COI gene sequences of the Common Hill Myna downloaded from GenBank were used as ingroup (Gracula religiosa GenBank Accession JF937590, G. religiosa BIN Seq. ID ROMC25807COI5P, and G. religiosa BIN Seq. ID ROMC25907COI5P) and two COI gene sequences from different species in Sturnidae were used as outgroup (Acridotheres cristatellus GenBank Accession JF810423 and A. tristis GenBank Accession HQ915864).

\section{RESULTS AND DISCUSSION}

\section{Nucleotide character and composition}

The length of the Enggano hill myna COI gene used for analysis was $716 \mathrm{bp}$ (Table 2). From those sequence, it was found $706(98.60 \%)$ conservative sites, $5 \quad(0.69 \%)$ parsimony sites, and $6(0.83 \%)$ singleton sites. Thymine was more frequently located in the first triplet codon (39.
$3 \%$ ), cytosine and adenine in the second codon with percentages each were $40.9 \%$ and $39.4 \%$, and guanine in the third codon $(29.5 \%)$. The length of the COI gene Enggano hill myna found in this study was longer than previous studies on barcode species (Hajibabaei et al. 2006; Huang and Tu 2016). However, it is shorter than the COI gene for seven Indonesian hornbill species (746 bp) (Jarulis et al. 2018) and Cockatoos (807 bp) (Astuti and Sulandari 2010). Usually, the COI gene's length for barcoding species is half the COI gene's total length (Sammler et al. 2011). Hebert et al. (2004) used the 648 bp COI gene for barcode species. Hajibabaei et al. (2006) stated that sequences 109$208 \mathrm{bp}$ in length could be used for species identification. The sequence length we obtain falls into the range of frequently used for species identification. Therefore, it can be used as a reference for identifying common hill myna around the world.

The highest nucleotide composition was cytosine $(32.20 \%)$, and the lowest was guanine $(16.80 \%)$ (Table 3 ). Next, we obtained $49 \%$ GC and 51\% AT content of the 716 bp length. The composition of GC and AT obtained in this study was almost the same as GC (47.0\%) and AT (53.0\%) Indonesian hornbills (Bucerotidae) (Jarulis et al. 2018). Similar results were also found in the Ardeidae $(\mathrm{GC}=$ $47.44 \%$, AT $=52.56 \%$ (Huang et al. 2016). However, in the eagle group (Accipitridae), GC (51.1\%) content was much higher than AT (48.9\%) (Zein 2018).

\section{Species identification}

The results of species identification using the BOLD System database are shown in Table 4. In Table 4, it is 
known that the Enggano hill myna COI gene sequence has a similarity between $98.83 \%$ and $99.83 \%$. The species identified in the similarity range is Gracula religiosa (BIN AAE7217) from India. This similarity percentage explains that the sequences tested are the same species with a difference of $<3.0 \%$. The difference between the species being compared is generally $>3 . \%$ (Hebert et al. 2003a; Vilaça et al. 2006; Efe et al. 2009). Based on the similarity with the COI gene sequences in the BOLD System database, the Enggano hill myna COI gene sequences are not yet available in GenBank. The COI gene nucleotide resulting from this study is considered new data that is potentially used as a reference for identifying common hill myna across the world. Taxonomists can use DNA barcoding as a tool for quick identification (Susanti et al. 2018).

\section{Substitution}

The number of nucleotide substitutions for the Enggano hill myna COI gene with 716 bp length is relatively small (Table 5). Transitional substitution events were not found in all triplet codons. However, the transversional substitution was found twice, namely in the second and third triplet codons. The average R-value was 0.6. The substitution frequency in Enggano hill myna was different from the results observed on other species. Jarulis et al. (2018) found 21 transitional substitutions and nine transversion substitutions in the seven hornbills COI gene. The same thing was also found in the Cacatua group (Astuti and Sulandari 2010). The R-value in the Enggano hill myna's COI gene sequence is almost the same as the four hornbill genera (0.6-3.7) (Jarulis et al. 2018). Zein (2018) found that the value of the transition/transversion bias in eagles (Accipitridae) is $\mathrm{R}=7.192$.

\section{Single nucleotide polymorphism}

The alignment results of the Enggano hill myna COI gene sequence $(716 \mathrm{bp})$ showed a difference with the common hill myna from China (Table 6). We found six single nucleotide polymorphisms (SNPs) in the Enggano hill myna COI gene sequence, located at 31, 32, 267, 326, 583, and 590 sites. These different sites can be called a specific site that is only found in Enggano hill myna and could be used as a barcode for the Enggano island population. The SNPs of Enggano hill myna were less than the SNPs among hornbill populations in Indonesia, 28 sites of the 746 bp sequence and positioned between 23 and 705 sites (Jarulis et al. 2018). According to Hebert et al. (2004) the diversity of nucleotides in the COI mtDNA gene sequence ( $648 \mathrm{bp}$ ) between animal taxon can be used as a barcode, and each species possesses typicality in the sequence of its COI gene with slight differences (Waugh 2007).

Table 2. Nucleotide character and codon position of Gracula religiosa enganensis $\mathrm{COI}$ gene at 716 bp length

\begin{tabular}{lccl}
\hline Character & $\boldsymbol{n}$ & $\begin{array}{l}\text { Total } \\
\text { base }\end{array}$ & $\begin{array}{l}\text { Number } \\
(\%)\end{array}$ \\
\hline Conservative site (\%) & 17 & 716 & $706(98.60)$ \\
Parsimony site (\%) & 17 & 716 & $5(0.69)$ \\
Singleton site (\%) & 17 & 716 & $6(0.83)$ \\
Variable site (\%) & 17 & 716 & $10(1.39)$ \\
Codon position for thymine & & & \\
$\quad$ First codon & 17 & 716 & 39.3 \\
$\quad$ Second codon & 17 & 716 & 14.3 \\
$\quad$ Third codon & 17 & 716 & 18.7 \\
Codon position for cytosine & 17 & 716 & \\
$\quad$ First codon & 17 & 716 & 28.4 \\
$\quad$ Second codon & 17 & 716 & 40.9 \\
$\quad$ Third codon & 17 & 716 & 27.7 \\
Codon position for adenine & & & \\
$\quad$ First codon & 17 & 716 & 16.8 \\
$\quad$ Second codon & 17 & 716 & 39.4 \\
$\quad$ Third codon & 17 & 716 & 24.4 \\
Codon position for guanine & & & \\
$\quad$ First codon & 17 & 716 & 15.5 \\
$\quad$ Second codon & 17 & 716 & 5.5 \\
$\quad$ Third codon & 17 & 716 & 29.5 \\
\hline
\end{tabular}

Note: $n$ : sample number

Table 3. Nucleotide composition of Gracula religiosa enganensis COI gene at 716 bp length

\begin{tabular}{|c|c|c|c|c|c|c|c|}
\hline Sample code & $\begin{array}{l}\text { Thymine } \\
\text { (T) }\end{array}$ & $\begin{array}{l}\text { Cytosine } \\
\text { (C) }\end{array}$ & $\begin{array}{c}\text { Adenine } \\
\text { (A) }\end{array}$ & $\begin{array}{c}\text { Guanine } \\
\text { (G) }\end{array}$ & $\begin{array}{c}\text { GC content } \\
(\%)\end{array}$ & $\begin{array}{c}\text { AT content } \\
(\%)\end{array}$ & Total base \\
\hline BE1COI & 24.00 & 32.30 & 26.80 & 16.90 & 49.20 & 50.80 & 716 \\
\hline BE2COI & 24.00 & 32.40 & 26.80 & 16.80 & 49.20 & 50.80 & 716 \\
\hline BE3COI & 24.20 & 32.10 & 26.80 & 16.90 & 49.00 & 51.00 & 716 \\
\hline BE4COI & 24.20 & 32.10 & 27.00 & 16.80 & 48.90 & 51.20 & 716 \\
\hline BE5COI & 24.20 & 32.30 & 26.80 & 16.80 & 49.10 & 51.00 & 716 \\
\hline BE6COI & 24.20 & 32.10 & 27.00 & 16.80 & 48.90 & 51.20 & 716 \\
\hline BE7COI & 24.20 & 32.30 & 26.80 & 16.80 & 49.10 & 51.00 & 716 \\
\hline BE8COI & 24.00 & 32.30 & 27.00 & 16.80 & 49.10 & 51.00 & 716 \\
\hline BE9COI & 24.00 & 32.30 & 26.80 & 16.90 & 49.20 & 50.80 & 716 \\
\hline BE10COI & 24.20 & 32.30 & 26.80 & 16.80 & 49.10 & 51.00 & 716 \\
\hline BE11COI & 24.00 & 32.40 & 26.80 & 16.80 & 49.20 & 50.80 & 716 \\
\hline BE12COI & 24.00 & 32.30 & 26.80 & 16.90 & 49.20 & 50.80 & 716 \\
\hline BE13COI & 24.30 & 32.10 & 26.80 & 16.80 & 48.90 & 51.10 & 716 \\
\hline BE14COI & 24.00 & 32.30 & 26.80 & 16.90 & 49.20 & 50.80 & 716 \\
\hline BE15COI & 24.00 & 32.10 & 27.10 & 16.80 & 48.90 & 51.10 & 716 \\
\hline BE16COI & 24.00 & 32.50 & 26.70 & 16.80 & 49.30 & 50.70 & 716 \\
\hline BE17COI & 23.90 & 32.10 & 27.10 & 16.90 & 49.00 & 51.00 & 716 \\
\hline Average & 24.10 & 32.20 & 26.90 & 16.80 & 49.00 & 51.00 & 716 \\
\hline
\end{tabular}


Table 4. Species identification result based on BoLD System database

\begin{tabular}{|c|c|c|c|c|c|}
\hline Species & Sample code & $\begin{array}{c}\text { Species identified } \\
\text { (Top 1) }\end{array}$ & $\begin{array}{c}\text { Similarity } \\
(\%)\end{array}$ & BIN & Collection location \\
\hline Gracula religiosa_l & BE1COI & Gracula religiosa & 98.83 & AAE7217 & India \\
\hline Gracula religiosa_2 & BE2COI & Gracula religiosa & 98.83 & AAE7217 & India \\
\hline Gracula religiosa_3 & BE3COI & Gracula religiosa & 99.00 & AAE7217 & India \\
\hline Gracula religiosa_4 & BE4COI & Gracula religiosa & 99.16 & AAE7217 & India \\
\hline Gracula religiosa_5 & BE5COI & Gracula religiosa & 99.16 & AAE7217 & India \\
\hline Gracula religiosa_6 & BE6COI & Gracula religiosa & 99.16 & AAE7217 & India \\
\hline Gracula religiosa_7 & BE7COI & Gracula religiosa & 99.16 & AAE7217 & India \\
\hline Gracula religiosa_8 & BE8COI & Gracula religiosa & 99.33 & AAE7217 & India \\
\hline Gracula religiosa_9 & BE9COI & Gracula religiosa & 99.00 & AAE7217 & India \\
\hline Gracula religiosa_10 & BE10COI & Gracula religiosa & 99.16 & AAE7217 & India \\
\hline Gracula religiosa_11 & BE11COI & Gracula religiosa & 99.33 & AAE7217 & India \\
\hline Gracula religiosa_12 & BE12COI & Gracula religiosa & 99.00 & AAE7217 & India \\
\hline Gracula religiosa_13 & BE13COI & Gracula religiosa & 99.33 & AAE7217 & India \\
\hline Gracula religiosa_14 & BE14COI & Gracula religiosa & 99.16 & AAE7217 & India \\
\hline Gracula religiosa_15 & BE15COI & Gracula religiosa & 99.16 & AAE7217 & India \\
\hline Gracula religiosa_16 & BE16COI & Gracula religiosa & 99.83 & AAE7217 & India \\
\hline Gracula religiosa_17 & BE17COI & Gracula religiosa & 99.16 & AAE7217 & India \\
\hline
\end{tabular}

Note: BIN: Barcode Index Number

Table 5. Substitution and nucleotide identical pair of Gracula religiosa enganensis COI gene in length 716 bp

\begin{tabular}{lccccc}
\hline \multicolumn{1}{c}{ Codon position } & $\boldsymbol{n}$ & Identical & Transitional & Transversional & R \\
\hline First codon & & 238 & 0 & 0 & 0 \\
Second codon & 17 & 238 & 0 & 1 & 0.3 \\
Third codon & 237 & 0 & 1 & 0.4 \\
Average & & 0 & 2 & 0.6 \\
\hline
\end{tabular}

Note: R: ratio si/sv.

Table 6. Single nucleotide polymorphism of Gracula religiosa enganensis COI gene at 716 bp length

\begin{tabular}{|c|c|c|c|c|c|c|c|}
\hline \multirow{2}{*}{ Species } & \multirow{2}{*}{ Sample code } & \multicolumn{6}{|c|}{ Nucleotide site } \\
\hline & & 31 & 32 & 267 & 326 & 583 & 590 \\
\hline Gracula religiosa* & GB AN JF937590 & A & $\mathrm{G}$ & $\mathrm{A}$ & $\mathrm{G}$ & $\mathrm{T}$ & $\mathrm{A}$ \\
\hline G. religiosa $* *$ & BIN Seq. ID ROMC25807COI5P & . & . & . & . & . & . \\
\hline G. religiosa $* *$ & BIN Seq. ID ROMC 25907 COI5P & . & $\dot{.}$ & . & . & . & . \\
\hline G. religiosa & BE1COI & $\mathrm{C}$ & $\dot{A}$ & G & A & $\mathrm{C}$ & G \\
\hline G. religiosa & $\mathrm{BE} 2 \mathrm{COI}$ & $\mathrm{C}$ & A & $\mathrm{G}$ & $\mathrm{A}$ & $\mathrm{C}$ & G \\
\hline G. religiosa & BE3COI & $\mathrm{C}$ & A & G & $\mathrm{A}$ & $\mathrm{C}$ & G \\
\hline G. religiosa & $\mathrm{BE} 4 \mathrm{COI}$ & $\mathrm{C}$ & $\mathrm{A}$ & $\mathrm{G}$ & A & $\mathrm{C}$ & G \\
\hline G. religiosa & BE5COI & $\mathrm{C}$ & A & $\mathrm{G}$ & A & $\mathrm{C}$ & G \\
\hline G. religiosa & BE6COI & $\mathrm{C}$ & A & $\mathrm{G}$ & A & $\mathrm{C}$ & G \\
\hline G. religiosa & BE7COI & $\mathrm{C}$ & A & G & A & $\mathrm{C}$ & G \\
\hline G. religiosa & BE8COI & $\mathrm{C}$ & A & $\mathrm{G}$ & $\mathrm{A}$ & $\mathrm{C}$ & $\mathrm{G}$ \\
\hline G. religiosa & BE9COI & $\mathrm{C}$ & A & $\mathrm{G}$ & A & $\mathrm{C}$ & G \\
\hline G. religiosa & BE10COI & $\mathrm{C}$ & A & $\mathrm{G}$ & A & $\mathrm{C}$ & G \\
\hline G. religiosa & $\mathrm{BE} 11 \mathrm{COI}$ & $\mathrm{C}$ & A & $\mathrm{G}$ & A & $\mathrm{C}$ & $\mathrm{G}$ \\
\hline G. religiosa & $\mathrm{BE} 12 \mathrm{COI}$ & $\mathrm{C}$ & A & $\mathrm{G}$ & A & $\mathrm{C}$ & $\mathrm{G}$ \\
\hline G. religiosa & BE13COI & $\mathrm{C}$ & A & $\mathrm{G}$ & A & . & $\mathrm{G}$ \\
\hline G. religiosa & BE14COI & $\mathrm{C}$ & A & $\mathrm{G}$ & A & $\mathrm{C}$ & $\mathrm{G}$ \\
\hline G. religiosa & BE15COI & $\mathrm{C}$ & A & G & A & . & G \\
\hline G. religiosa & BE16COI & $\mathrm{C}$ & A & $\mathrm{G}$ & A & $\dot{\mathrm{C}}$ & $\mathrm{G}$ \\
\hline G. religiosa & $\mathrm{BE} 17 \mathrm{COI}$ & $\mathrm{C}$ & A & G & A & . & G \\
\hline
\end{tabular}

Note: *: NCBI database, **: BOLD System database. Numbers below nucleotide base site names are site numbers for each base change in our alignment for the COI gene. Site one in our alignment is equivalent to site 254 in the full Gracula religiosa sequence (GenBank Accession JF937590) 


\section{Genetic distance}

The genetic distance of intrapopulation and interpopulation common hill myna is shown in Table 7. In Table 7, it is known that the genetic distance between individuals in the Enggano hill myna population was 0.000-0.008 (average $0.003=0.3 \%$ ). Genetic distance between the Enggano and Chinese populations (Gracula religiosa GenBank Accession JF937590) was 0.009 $(0.9 \%)$, and the Indian population $(G$. religiosa BIN Seq. ID ROMC25907COI5P) was 0.011 (1.1\%). Furthermore, the genetic distance between Chinese and Indian common hill myna was $0.002(0.2 \%)$. Based on the genetic distance between these populations, the Enggano hill myna population is still classified as a sub-species. The results of genetic distances between populations in this study are similar to some of the previous data. Jarulis et al. (2018) found that genetic distances between hornbill populations ranged between $0.002(0.2 \%)$ and $0.008(0.8 \%)$. This study results also shown similarity to several previous ornithology research (Yoo et al. 2006; Astuti and Sulandari 2010; Huang and Tu 2016).

The genetic distance between populations can be used to explain taxon status. When the genetic distance between populations meets the requirements for a difference of $>3.0 \%$, the subpopulation can be stated as a different species (Hebert et al. 2003a). Genetic distance between populations is generally less than $1.0 \%$ and rarely more than $2.0 \%$ (Waugh 2007). For example, the genetic distance between populations of Korean bird species and the Phasianidae group is a maximum of $0.3 \%$ (Yoo et al. 2006; Cai et al. 2010). Tavares et al. (2011) found the genetic distance between populations of Neotropical birds ranged from 0.0 to $13.7 \%$. Another study by Gonçalves et al. (2015) showed that parrots' genetic distance was 0.1 to $0.7 \%$.

The interspecies genetic distances were found to meet the requirements for differentiation between species (Table 7). Table 7 shows the average genetic distance between common hill myna (ingroup) and crested myna Acridotheres cristatellus and common myna Acridotheres tristis (outgroup) in the same family (Sturnidae) was 0.121 (12.1\%). This study's genetic distance similar to previous studies and fulfilled the interspecies genetic distance threshold of $>3.0 \%$ (Hebert et al. 2004). To get a more accurate identification result, the genetic distance between species should be above 5.0\% (Waugh 2007). The difference in COI genes between Laridae (Sternini) species ranged from 0.25 to $10.51 \%$ (Efe et al. 2009). Jarulis et al. (2018) found a genetic distance between Anthracoceros malayanus and A. albirostris was 0.032 (3.2\%). The mean divergence of the COI gene within genera in Korean birds was $8.2 \%$ (Yoo et al. 2006); 4.8\%-15.6\% within Thamnophilidae (Passeriformes) (Vilaça et al. 2006); $7.95 \%$ on Scandinavian birds (Johnsen et al. 2010); $5.35 \%$ on Phasianidae (Cai et al. 2010); 9.52\% on Green bee-eater (Merops orientalis) (Arif et al. 2011); 13.08\% within the genus in Ardeidae (Huang and $\mathrm{Tu}$ 2016); 0.0-13.1\% between duck species (Susanti et al. 2018).

\section{Phylogenetic}

The phylogenetic tree reconstruction of Enggano hill myna and other common hill myna in the world based on the NJ model is shown in Figure 2. In Figure 2, it is known that the Enggano hill myna population is far apart from the China and India populations, with a bootstrap value of 2099. However, it was seen that two individuals (BE15COI and BE17COI) were slightly separated from other individuals and clustered in different clusters with a genetic distance of $0.005(0.5 \%)$ and a bootstraps value of 87 . All common hill myna were clustered in the ingroup and separated from the outgroup with a genetic distance of $0.121(12.1 \%)$. These data suggest the Enggano hill myna population is a different sub-species, geographically isolated from other populations, including Chinese and Indian populations with a bootstrap value of 94 and a genetic distance of 0.01 (1.0\%). Lovette and Rubenstein (2007) reported that the common hill myna group is more closely related to the Ampeliceps coronatus based on mitochondrial protein-coding sequence (4116 bp nucleotide) and Achridoteres spp. adjacent to the Sturnus spp. Gracula religiosa religiosa has a close kinship with $G$. $r$. miotera and G. $r$. batuensis based on the ND2 mtDNA gene (Dominic et al. 2020).

The phylogenetic tree of COI genes constructed from this study gave insight into separating the intraspecies of common hill myna. The accuracy of the kinship test based on the COI gene sequence was considered reliable. Tree branches represent the relationships among units by tracing backward the hereditary track to the nearest ancestors. The branches' length tells the number of evolutionary changes that occurred between the two nodes (Li and Graur 2000). The sequence diversity of COI genes retains potential use for identification on the species level, in addition, to become DNA barcode (Hebert et al. 2003a, b; Hebert and Gregory 2005). Huang and Tu (2016) suggested that DNA barcoding based on COI has been successful in species determination and phylogeny across animal species. This COI gene has also shown satisfactory results for animal identification (Hajibabaei et al. 2006). 
Table 7. Pairwise distance between Gracula religiosa enganensis and other population-based on partial COI gene in 746 length

\begin{tabular}{|c|c|c|c|c|c|c|c|c|c|c|c|c|c|c|c|c|c|c|c|c|c|c|}
\hline Sample code & 1 & 2 & 3 & 4 & 5 & 6 & 7 & 8 & 9 & 10 & 11 & 12 & 13 & 14 & 15 & 16 & 17 & 18 & 19 & 20 & 21 & 22 \\
\hline 1. BE1COI & & & & & & & & & & & & & & & & & & & & & & \\
\hline 2. BE14COI & 0.0016 & & & & & & & & & & & & & & & & & & & & & \\
\hline 3. BE2COI & 0.0000 & 0.0016 & & & & & & & & & & & & & & & & & & & & \\
\hline 4. BE16COI & 0.0016 & 0.0033 & 0.0016 & & & & & & & & & & & & & & & & & & & \\
\hline 5. BE9COI & 0.0016 & 0.0033 & 0.0016 & 0.0033 & & & & & & & & & & & & & & & & & & \\
\hline 6. BE12COI & 0.0016 & 0.0033 & 0.0016 & 0.0033 & 0.0000 & & & & & & & & & & & & & & & & & \\
\hline 7. BE3COI & 0.0049 & 0.0066 & 0.0049 & 0.0049 & 0.0033 & 0.0033 & & & & & & & & & & & & & & & & \\
\hline 8. BE4COI & 0.0033 & 0.0049 & 0.0033 & 0.0033 & 0.0016 & 0.0016 & 0.0016 & & & & & & & & & & & & & & & \\
\hline 9. BE5COI & 0.0033 & 0.0049 & 0.0033 & 0.0033 & 0.0016 & 0.0016 & 0.0016 & 0.0000 & & & & & & & & & & & & & & \\
\hline 10. BE10COI & 0.0033 & 0.0049 & 0.0033 & 0.0033 & 0.0016 & 0.0016 & 0.0016 & 0.0000 & 0.0000 & & & & & & & & & & & & & \\
\hline 11. BE6COI & 0.0033 & 0.0049 & 0.0033 & 0.0033 & 0.0016 & 0.0016 & 0.0016 & 0.0000 & 0.0000 & 0.0000 & & & & & & & & & & & & \\
\hline 12. BE7COI & 0.0033 & 0.0049 & 0.0033 & 0.0033 & 0.0016 & 0.0016 & 0.0016 & 0.0000 & 0.0000 & 0.0000 & 0.0000 & & & & & & & & & & & \\
\hline 13. BE8COI & 0.0049 & 0.0066 & 0.0049 & 0.0049 & 0.0033 & 0.0033 & 0.0033 & 0.0016 & 0.0016 & 0.0016 & 0.0016 & 0.0016 & & & & & & & & & & \\
\hline 14. BE11COI & 0.0049 & 0.0066 & 0.0049 & 0.0049 & 0.0033 & 0.0033 & 0.0033 & 0.0016 & 0.0016 & 0.0016 & 0.0016 & 0.0016 & 0.0000 & & & & & & & & & \\
\hline 15. BE13COI & 0.0049 & 0.0066 & 0.0049 & 0.0049 & 0.0033 & 0.0033 & 0.0033 & 0.0016 & 0.0016 & 0.0016 & 0.0016 & 0.0016 & 0.0033 & 0.0033 & & & & & & & & \\
\hline 16. BE15COI & 0.0066 & 0.0083 & 0.0066 & 0.0049 & 0.0049 & 0.0049 & 0.0066 & 0.0049 & 0.0049 & 0.0049 & 0.0049 & 0.0049 & 0.0049 & 0.0049 & 0.0033 & & & & & & & \\
\hline 17. BE17COI & 0.0066 & 0.0083 & 0.0066 & 0.0049 & 0.0049 & 0.0049 & 0.0066 & 0.0049 & 0.0049 & 0.0049 & 0.0049 & 0.0049 & 0.0049 & 0.0049 & 0.0033 & 0.0000 & & & & & & \\
\hline $\begin{array}{l}\text { 18. Gracula religiosa } \\
\text { (GB AN JF937590) }\end{array}$ & 0.0116 & 0.0133 & 0.0116 & 0.0116 & 0.0099 & 0.0099 & 0.0100 & 0.0083 & 0.0083 & 0.0083 & 0.0083 & 0.0083 & 0.0066 & 0.0066 & 0.0066 & 0.0083 & 0.0083 & & & & & \\
\hline $\begin{array}{l}\text { 19. G. religiosa (BIN Seq. } \\
\text { ID ROMC25807COI5P) }\end{array}$ & 0.0116 & 0.0133 & 0.0116 & 0.0116 & 0.0099 & 0.0099 & 0.0100 & 0.0083 & 0.0083 & 0.0083 & 0.0083 & 0.0083 & 0.0066 & 0.0066 & 0.0066 & 0.0083 & 0.0083 & 0.0000 & & & & \\
\hline $\begin{array}{l}\text { 20. G. religiosa (BIN Seq. } \\
\text { ID ROMC25907COI5P) }\end{array}$ & 0.0133 & 0.0149 & 0.0133 & 0.0133 & 0.0116 & 0.0116 & 0.0116 & 0.0100 & 0.0100 & 0.0100 & 0.0100 & 0.0100 & 0.0083 & 0.0083 & 0.0083 & 0.0099 & 0.0099 & 0.0016 & 0.0016 & & & \\
\hline $\begin{array}{l}\text { 21. Acridotheres cristatellus } \\
\text { (GB AN JF810423) }\end{array}$ & 0.1223 & 0.1242 & 0.1223 & 0.1224 & 0.1204 & 0.1204 & 0.1165 & 0.1185 & 0.1185 & 0.1185 & 0.1185 & 0.1185 & 0.1165 & 0.1165 & 0.1165 & 0.1184 & 0.1184 & 0.1205 & 0.1205 & 0.1225 & & \\
\hline $\begin{array}{l}\text { 22. A. tristis } \\
\text { (GB AN HQ915864) }\end{array}$ & 0.1243 & 0.1262 & 0.1243 & 0.1244 & 0.1224 & 0.1224 & 0.1185 & 0.1205 & 0.1205 & 0.1205 & 0.1205 & 0.1205 & 0.1185 & 0.1185 & 0.1185 & 0.1204 & 0.1204 & 0.1225 & 0.1225 & 0.1245 & 0.0374 & \\
\hline
\end{tabular}




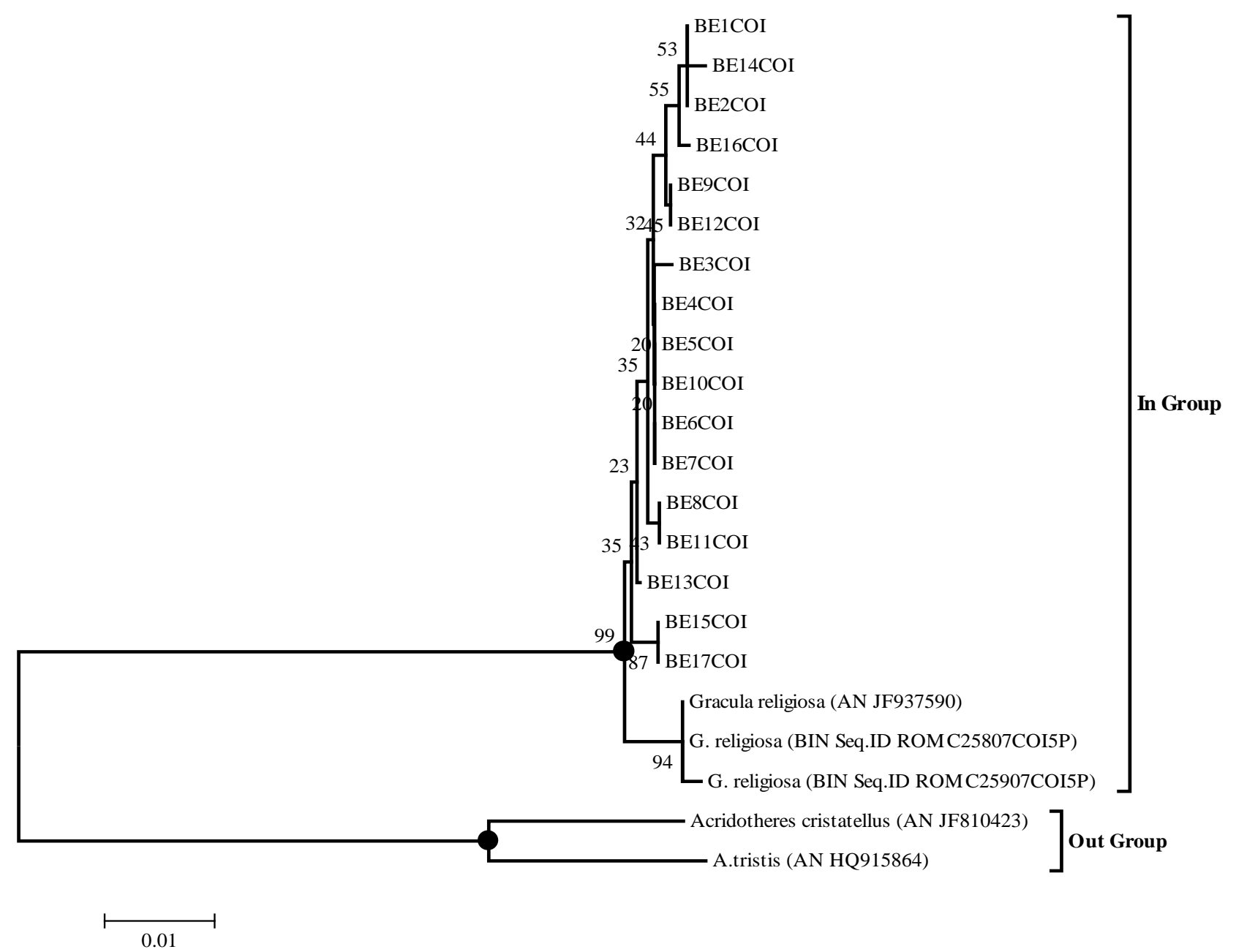

Figure 2. Neighbor-Joining (NJ) phylogenetic tree of Enggano hill myna (Gracula religiosa enganensis) from Enggano island based on a partial COI gene sequence with 716 bp length

This study confirms that the Enggano hill mynas are phylogenetically separated from other hill myna subspecies, albeit our result did not support it as separate species. While currently safe to put Enggano hill myna as a sub-species from common hill myna, we suggest to collect more molecular data from the distribution of this species in order to establish more robust status for taxa it shelters.

\section{ACKNOWLEDGEMENTS}

We would like to thank the Bengkulu University for funding this research through the Unggulan Unib grant in 2020 (contract number 1980/UN30.15/PG/2020). We were grateful to BKSDA Bengkulu for the four Enggano hill myna blood samples. We also thanked Muhammad Nazri Janra and David Gusman, who helped us improve this manuscript's quality. The authors were grateful to Mr. Alamsyah for his assistance in collecting Enggano hill myna blood samples in the Enggano island and our laboratory colleagues for their assistance in this study.

\section{REFERENCES}

Anon. 2018. Regulation of the minister of environment and forestry of Indonesia No. P.106 year 2018 about the second changes of regulation of the minister of environment and forestry of Indonesia No. P.20 year 2018 about the protection of animal and plant species. Ministry of Environment and Forestry, Jakarta. [Indonesian].

Arif IA, Khan HA, Shobrak M, Williams J. 2011. Cytochrome c oxidase subunit I barcoding of the green bee-eater (Merops orientalis). Genet Mol Res 10: 3992-3998. DOI: 10.4238/2011.October.21.2.

Astuti D, Sulandari S. 2010. The DNA sequence performance of COI gene in White cockatoos (Cacatua, Psittaciformes). Treubia 37: 1-14.

Cai Y, Yue B, Jiang W, Xie S, Li J, Zhou M. 2010. DNA barcoding on subsets of three families in Aves. Mitochondrial DNA 21: 132-137. DOI: $10.3109 / 19401736.2010 .494726$.

Dominic YJN, Svejcarova T, Sadanandan KR, Ferasyi TR, Lee JGH, Prawiradilaga DM, Ouhel T, Elize YXN, Rheindt FE. 2020. Genomic and morphological data help uncoverextinction-in-progress of an unsustainably traded hill myna radiation. Ibis: 38-51. DOI: 10.1111/ibi.12839.

Eaton JA, van Balen B, Brickle NW, Rheindt FE. 2016. Birds of the Indonesia Archipelago: Greater Sundas and Wallacea. Lynx EditionMontseny, Barcelona.

Efe MA, Tavares ES, Baker AJ, Bonatto SL. 2009. Multigene phylogeny and DNA barcoding indicate that the Sandwich tern complex (Thalasseus sandvicensis, Laridae, Sternini) comprises two species. $\begin{array}{llll}\text { Mol Phylogenet Evol 52: 263-267. DOI: } & \end{array}$ 10.1016/j.ympev.2009.03.030. 
Gonçalves PFM, Marques ARO, Matsumoto TE, Miyaki CY. 2015. DNA barcoding identifies illegal parrot trade. J Hered 106: 560-564. DOI: 10.1093/jhered/esv035.

Gonzales JCT, Sheldon BC, Collar NJ, Tobias JA. 2013. A comprehensive molecular phylogeny for the hornbills (Aves: Bucerotidae). Mol Phylogenet Evol 67: 468-483. DOI: 10.1016/j.ympev.2013.02.012.

Hajibabaei M, Smith MA, Janzen DH, Rodriguez JJ, Whitfield JB, Hebert PDN. 2006. A minimalist barcode can identify a specimen whose DNA is degraded. Mol Ecol 6: 959-964. DOI: 10.1111/j.1471 8286.2006.01470.x.

Hall TA. 1999. BioEdit: a user-friendly biological sequence alignment editor and analysis program for Windows 95/98/NT. Nucl Acids Symp Ser 41: 95-98.

Harrisson C, Greensmith A. 2003. Birds of the World. Dorling Kindersley, London.

Hebert PDN, Cywinska A, Ball SL, deWaard JR. 2003a. Biological identifications through DNA barcodes. Proc R Soc Lond B Biol Sci 270 (1512): 313-321. DOI: 10.1098/rspb.2002.2218.

Hebert PDN, Gregory TR. 2005. The promise of DNA barcoding for taxonomy. Syst Biol 54: 852-859. DOI: 10.1080/10635150500354886.

Hebert PDN, Ratnasingham S, deWaar JR. 2003b. Barcoding animal life: cytochrome $\mathrm{c}$ oxidase subunit 1 divergence among closely related species. Proc R Soc Lond B Biol Sci 270 (Suppl 1): S96-S99. DOI 10.1098/rsbl.2003.0025.

Hebert PDN, Stoeckle MY, Zemlak TS, Francis CM. 2004. Identification of birds through DNA barcodes. PLoS Biol 2: e312. DOI: 10.1371/journal.pbio.0020312.

Huang Z, Tu F. 2016. DNA barcoding and phylogeny of Calidris and Tringa (Aves: Scolopacidae). Mitochondrial DNA. DOI: 10.3109/ 24701394.2016.1155121.1-4.

Huang ZH, Li MF, Qin JW. 2016. DNA barcoding and phylogenetic relationships of Ardeidae (Aves: Ciconiiformes). Genet Mol Res 15 (3): gmr.15038270. DOI: 10.4238/gmr.15038270

Jarulis, Solihin DD, Mardiastuti A, Prasetyo LB. 2018. DNA barcode of seven Indonesian hornbills species (Aves: Bucerotidae) based on mitochondrial DNA cytochrome oxidase subunit I. Hayati 25 (4): 178-187. DOI: 10.4308/hjb.25.4.178.

Johnsen A, Rindal E, Ericson PGP, Zuccon D, Kerr KCR, Stoeckle MY Lifjeld JT. 2010. DNA barcoding of Scandinavian birds reveals divergent lineages in trans-Atlantic species. J Ornithol 151: 565-578. DOI: $10.1007 / \mathrm{s} 10336-009-0490-3$.

Kimura M. 1980. A simple method for estimating evolutionary rates of base substitutions through comparative studies of nucleotide sequences. J Mol Evol 16: 111-120. DOI: 10.1007/BF01731581.

Kumar S, Stecher G, Li M, Knyaz C, Tamura K. 2018. MEGA X: Molecular evolutionary genetics analysis across computing platforms. Mol Biol Evol 35:1547-1549. DOI: 10.1093/molbev/msy096.

Li WH, Graur D. 2000. Fundamentals of Molecular Evolution. Second edition. Sinauer Associates Inc, Sunderland, USA.
Lovette IJ, Rubenstein DR. 2007. A comprehensive molecular phylogeny of the starling (Aves: Sturnidae) and mockingbirds (Aves: Mimidae): Congruent mtDNA and nuclear trees for a cosmopolitan avian radiation. Mol Phylogenet Evol 44: 1031-1056. DOI: 10.1016/j.ympev.2007.03.017

MacKinnon J, Philipps K, van Balen B. 2010. Birds of Sumatra, Java, Bali, and Borneo (including Sabah, Sarawak, and Brunei Darussalam). LIPI, Bogor. [Indonesian].

Sambrook J, Fritsch EF, Maniatis T. 1989. Molecular cloning: A laboratory manual. Cold Spring Harb Lab Press, New York.

Sammler S, Bleidorn C, Tiedemann R. 2011. Full mitochondrial genome sequences of two endemic Philippine hornbill species (Aves: Bucerotidae) provide evidence for pervasive mitochondrial DNA recombination. BMC Genom 12: 35. DOI: 10.1186/1471-2164-12-35.

Seutin G, White BN, Boag PT. 1991. Preservation of avian blood and tissue samples for DNA analysis. Can J Zool 69: 82-90. DOI: 10.1139/z91-013.

Sibley CG, Ahlquist JE. 1990. Phylogeny and Classification of Birds. A Study in Molecular Evolution. Yale University Press, New Haven \& London.

Siregar J. 1997. Sexing and Genotype Variation of Nias Hill Myna (Gracula religiosa robusta). Conservation of Forest Resources Department. Forestry Faculty, IPB, Bogor. [Indonesian].

Sukmantoro W, Irham M, Novarino W, Hasudungan F, Kemp N, Muchtar M. 2007. Checklist of Indonesian Birds No. 2. Indonesian Ornithologists' Union, Bogor. [Indonesian].

Susanti R, Iswari RS, Fibriana F, Indriawati. 2018. The duck cytochrome oxidase I (COI) gene: Sequence and patterns analysis for potential barcoding tool. Biodiversitas 19 (3): 997-1003. DOI: 10.13057/biodiv/d190331.

Susanti R. 2011. Polymorphic sequence in the ND3 region of Java endemic Ploceidae birds mitochondrial DNA. Biodiversitas 12 (2): 70-75. DOI: 10.13057/biodiv/d120203.

Suzanna E. 2007. Analysis of kinship based on morphology, daily activities, blood and characteristics of mitochondrial DNA in some subspecies of common hill myna (Gracula religiosa L. 1758). Conservation of Forest Resources Department. Forestry Faculty, IPB, Bogor. [Indonesian].

Tavares ES, Alves PG, Miyaki CY, Baker AJ. 2011. DNA barcode detects high genetic structure within neotropical bird species. PLoS ONE 6: e28543. DOI: 10.1371/journal.pone.0028543.

Vilaça ST, Lacerda DR, Sari EHR, Santos FR. 2006. DNA-based identification applied to Thamnophilidae (Passeriformes) species: the first barcodes of Neotropical birds. Revista Brasileira de Ornitologia 14: 7-13.

Waugh J. 2007. DNA barcoding in animal species: progress, potential and pitfalls. Bioessays 29: 188-197. DOI: 10.1002/bies.20529.

Yoo HS, Eah JY, Kim JS, Kim YJ, Min MS, Paek WK, Lee H, Kim CB. 2006. DNA barcoding Korean birds. Mol Cells 22: 323-327. DOI: 10.1007/s10059-013-3151-6.

Zein MSA. 2018. DNA barcode of eagle (Accipitridae) in Indonesia. Ber Biol 17 (2): 165-173. [Indonesian] 